\title{
An Analysis of Critical Issues in Korean Teacher Evaluation Systems
}

Hee Jun ChOi ${ }^{1}$ AND Ji-Hye PARK ${ }^{\star 2}$

$\approx$ Korea has used three different teacher evaluation systems since the 1960s: teacher performance rating, teacher performance-based pay and teacher evaluation for professional development. A number of studies have focused on an analysis of each evaluation system in terms of its advent, development, advantages and disadvantages, but these studies have been critically limited in that they have focused only on the partial integration of the three current teacher evaluation systems, without addressing the problems embedded in each of them. The present study provides a systematic analysis of the three current Korean teacher evaluation systems based on a sound analytical framework and proposes appropriate directions for designing an effective and efficient system. It is found that the three systems share commonalities in terms of stakeholders, evaluators, scope, criteria and methods, further supporting the rationale for developing a single comprehensive teacher evaluation system in Korea. Finally, several steps to establish a comprehensive teacher evaluation system based on the analysis results are suggested.

Keywords: Korea teacher evaluation system, teacher evaluation for professional development, teacher performance-based pay system, teacher performance rating 


\section{Analiza ključnih problemov v korejskem evalvacijskem sistemu učiteljev}

Hee Jun Choi in Ji-Hye Park

$\propto$ Koreja je od leta 1960 uporabljala naslednje tri evalvacijske sisteme učiteljev: ocenjevanje uspešnosti učiteljev, plačilo na osnovi uspešnosti učiteljev in ocenjevanje strokovnega razvoja učiteljev. Številne študije so se osredinjale na analizo vsakega izmed evalvacijskih sistemov v smislu njihovih začetkov, razvoja, prednosti in pomanjkljivosti. Njihova ključna omejitev je bila v tem, da so se osredinjale le na delno integracijo treh obstoječih sistemov evalvacije učiteljev, ne da bi naslavljale probleme, ki se pojavljajo v vsakem izmed teh. Ta študija daje sistematično analizo treh obstoječih korejskih sistemov za evalvacijo učiteljev, ki temelji na tehtnem analitičnem okviru ter predlaga primerne usmeritve za učinkovit in uspešen sistem. Študija pokaže, da so vsem trem sistemom skupni deležniki, evalvatorji, področja, merila in metode, kar še krepi razloge za razvoj enega samega skupnega sistema evalvacije učiteljev v Koreji. Na koncu so predlagani številni koraki v smeri vzpostavitve skupnega sistema evalvacije, ki temelji na analizi rezultatov.

Ključne besede: korejski evalvacijski sistem učiteljev, ocenjevanje strokovnega razvoja učiteljev, plačilo na osnovi uspešnosti učiteljev, ocenjevanje uspešnosti učiteljev 


\section{Introduction}

Teacher quality is a core educational issue throughout the world. Indeed, many research studies have indicated that the quality of teachers is the single most significant factor determining the quality of a student's education (National Commission on Teaching and America's Future, 1996; GreatKids, n. d.). Since teacher evaluation is essential in providing students with the best educational experience possible and is at the centre of the quality of teaching and learning in the classroom (Strong \& Tucker, 2012; Toch \& Rothman, 2008), many efforts have been made to establish efficient and effective teacher evaluation systems in a range of countries. For example, the effort to transform the evaluation system for teachers across their career span is at the heart of education policy efforts in the U.S., in association with President Obama's Race to the Top Initiative, which incentivises states adopting new evaluation systems that link teacher evaluation to student outcomes (Clayton, 2013).

Korean parents are passionate about educating their children and place heavy demands on the public education system, as well as on individual teachers within the system. Currently, some of the foremost problems surrounding the Korean education system involve the use of private tutoring, distrust of public education and excessive performance pressure placed on students (Choi \& Park, 2013). In particular, the issue of distrust of public education, resulting in the use of private tutoring, is the most urgent education problem upon which administrators need to focus their attention, and this directly relates to the issue of teacher quality. Thus, the development of a valid and reliable teacher evaluation system is a critical starting point in regaining people's trust in public education.

Korea has implemented three different teacher evaluation systems since the 196os: teacher performance rating, teacher performance-based pay system and teacher evaluation for professional development. First adopted in 1964, teacher performance ratings evaluate teachers' past, current and potential performance, and aid decision-making regarding promotion and school transferal. The teacher performance-based pay system, first introduced in 2001, further aims to generate constructive competition between teachers and offers monetary rewards for their efforts. Finally, the teacher evaluation for professional development system, established nationwide in 2010, provides teachers with corrective feedback on their teaching and, in turn, assists in the development of their professional competence. Due to the unique nature of the teacher community in Korea, when the need for enhanced teacher evaluation was identified, a new type of teacher evaluation system was developed and implemented, rather than the existing system being revised or transformed. Consequently, there is criticism that teachers 
are evaluated under three different evaluation systems, each with different underlying assumptions and evaluation standards, which both complicates the evaluation system and increases teacher workload (Jeon, 2009).

A number of studies have focused on an analysis of each evaluation system in terms of its advent, development, advantages and disadvantages (e.g., Kang \& Kim, 2004; Kim, Park, \& Joo, 2009; Lee, 2006; Park, 2010). These studies have, however, mainly focused on one of the three individual evaluation systems, with little attention being paid to an integrated analysis of the three systems as a whole. On the other hand, several studies have aimed to explore the possibility of integrating certain parts of each evaluation system, investigating the feasibility of developing an integrated system of teacher evaluation (Jeon, 2009; Kim \& Joo, 2014; Kim, Jung, Jeon, Shin, \& Kang, 2010; Park, Choi, \& Choi, 2009). For example, Jeon (2009) proposed the possibility of integrating teacher evaluation for professional development and performance rating for promotion, as both are based on common evaluation areas (i.e., instruction and student guidance). Similarly, Kim and Joo (2014) suggested certain changes and modifications to the evaluation system based on comparative and correlational analyses of results from the three systems, combined with the results of a comprehensive survey among stakeholders. Additionally, Kim et al. (2010) proposed four alternatives for the integration of the three evaluation systems: the first option was to retain the three systems with minor revisions to each; the second option was to combine performance ratings for promotion with the performance-based pay system and to leave teacher evaluation for professional development as it is; the third option was to replace the evaluation results for instruction and student guidance of the performance-based pay system with those of teacher evaluation for professional development; and the final option was to combine teacher evaluation for professional development with performance ratings for promotion. Nevertheless, these studies have been critically limited in that they have focused only on the partial integration of the three current teacher evaluation systems, without addressing the problems embedded in each of them.

The current Korean government is attempting to revise the teacher evaluation systems, as one of the main election pledges offered by the incumbent President was to solve the problems of the three systems. Since the systems were designed and introduced to meet the particular social needs at the time, careful consideration and revision are now required for an integrated system. Accordingly, the present paper aims to provide a systematic analysis of the three current Korean teacher evaluation systems based on a sound analytical framework, and to propose appropriate directions for designing an effective and efficient system. 


\section{Analytical Framework}

The study reported here adopts a two-tier analytical framework consisting of a conceptual framework for teacher evaluation and criteria for an effective teacher evaluation system. In 2009, Isoré presented a conceptual framework for teacher evaluation that reflects the main features of current teacher evaluation systems. This framework involves a variety of components generally used to evaluate teachers, including stakeholders, the scope of evaluation, evaluators, criteria and standards, and methods and instruments, as well as identifying potential consequences in summative and formative teacher assessments (Figure 1). Furthermore, Isoré (2009) suggested that this conceptual framework emphasises the clarification of the main purposes of each teacher evaluation system. This implies that Isorés (2009) conceptual framework for teacher evaluation is useful as a basic tool to provide an overview of a teacher evaluation system in terms of the coherence of its components in successfully achieving its main purpose. Accordingly, the present study utilises this conceptual framework for teacher evaluation as an initial analytical framework to analyse the three teacher evaluation systems currently used in Korea.

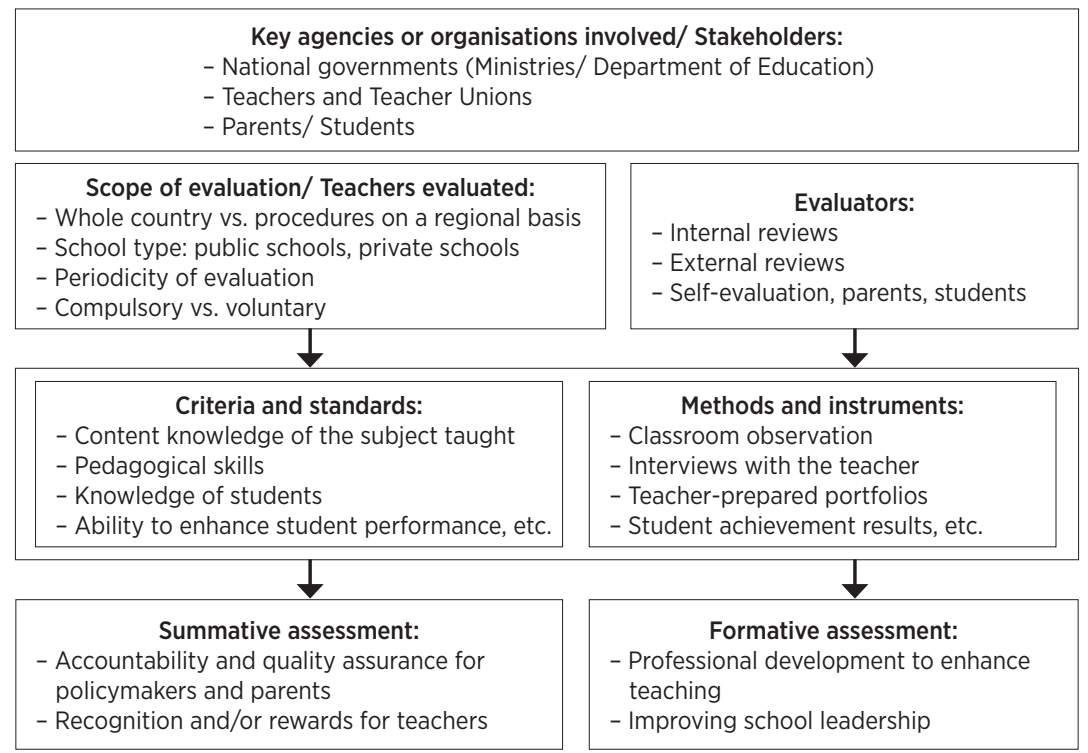

Figure 1. Adopted from the conceptual framework for teacher evaluation (Isoré, 2009) 
On the other hand, Darling-Hammond (2013) recently proposed criteria for an effective teacher evaluation system based on an analysis of a range of comprehensive teacher evaluation systems used in many schools and districts throughout the U.S. These criteria are useful to determine the critical issues embedded in a teacher evaluation system, which are required for both judging its effectiveness and improving it. Darling-Hammond (2013) summarised the criteria for an effective teacher evaluation system as follows:

- The teacher evaluation should be based on professional teaching standards;

- Evaluations should include multifaceted evidence of teacher practice, student learning and professional contributions;

- $\quad$ Evaluators should be knowledgeable about instruction and well trained in the evaluation system;

- $\quad$ Evaluation should be accompanied by useful feedback, and connected to professional development opportunities;

- $\quad$ The evaluation system should value and encourage teacher collaboration;

- $\quad$ Expert teachers should be part of the assistance and review process;

- Panels of teachers and administrators should oversee the evaluation process. (p.153)

The present study adopts these criteria for an effective teacher evaluation system as an analytical framework to facilitate the proposal of an ideal integrated system that can simultaneously attain the goals of the three different existing systems by determining priority issues to be addressed.

\section{Performance Rating for Promotion}

A presidential executive order of 1963 regarding the promotion of public education officials prompted the adoption of a system of teacher performance ratings for promotion in 1964. According to this regulation (recently amended on 4 November 2014), teacher performance ratings aim to ensure fair and objective personnel management and promotion. The main format of the rating remains, but several aspects (e.g., evaluation criteria and their weightings, the rating cycle, the evaluators, etc.) have been revised over the course of approximately 30 partial or complete amendments of the regulations (Jeon, 2009).

Currently, teacher performance ratings for promotion targets two groups: teachers and vice-principals. Although the rating system has the same purpose for the two groups (i.e., to ensure fair and objective personnel management and promotion), several aspects (e.g., evaluation areas and evaluators) are 
quite different. In addition, the evaluation does not concern principals, as they fill the highest ranked position within a school, with no scope for promotion. For this evaluation, teachers and vice-principals are required to submit a selfreport on performance by 31 December of every year. Teachers' self-reports are evaluated by the principal, the vice-principal and three or more peer teachers, with weightings of $30 \%, 40 \%$ and $30 \%$, respectively. Vice-principals are evaluated by the principal (with a weighting of 50\%) and the education policy supervisor of the municipal Ministry of Education (with a weighting of 50\%). The total possible score is 100 points, but the evaluation is, in principle, norm-referenced and designed to compare and rank teachers in relation to one another. Specifically, only $30 \%$ of teachers in a school can achieve an A, 40\% a B, 20\% a C and $10 \%$ a D. The same percentages apply to vice-principals in a school district.

This performance rating for promotion system of evaluation covers two evaluation areas: "qualification and attitude" for both groups, "management and support" for vice-principals and "work performance" for teachers. Attitude is measured using a number of elements, including "characteristics as an educator" and "attitude as a public official". Elements of work performance differ for the two groups. The elements for teachers include "instruction", "student guidance", and "educational research and administrative service", while those for vice-principals include "support for educational activities and research", "teacher support", and "administration and management". The questions relating to each element also differ between the groups. An example of a question targeting a teacher's "characteristics as an educator" is "Does (s)he gain trust and respect from students and parents?"; whereas, for a vice-principal, an example is "Does (s)he gain the trust and respect of school community members?" These questions are given to the evaluators, who subsequently rate teachers' or viceprincipals' performances by answering the questions and considering the previously submitted self-reports. The evaluation areas, elements and questions for vice-principals and teachers are presented in Table 1 and Table 2, respectively.

The information obtained from the performance rating described herein informs decision-making regarding transfers between schools and promotions. The evaluation results are available to the individual upon request. 
Table 1. Performance rating for promotion evaluation standards for teachers

\begin{tabular}{|c|c|c|}
\hline Areas & Elements & Questions \\
\hline \multirow[t]{2}{*}{$\begin{array}{l}\text { Qualification } \\
\text { \& attitude }\end{array}$} & $\begin{array}{l}\text { Characteristics } \\
\text { as an educator }\end{array}$ & $\begin{array}{l}\text { Does (s)he take responsibility for and pride in his (her) mission } \\
\text { and duties as a teacher? } \\
\text { Does (s)he have integrity and courteousness as an educator? } \\
\text { Is (s)he devoted to education based on understanding and love } \\
\text { of students? } \\
\text { Does (s)he gain the trust and respect of students and their } \\
\text { parents? }\end{array}$ \\
\hline & $\begin{array}{l}\text { Attitude as a } \\
\text { public official }\end{array}$ & $\begin{array}{l}\text { Does (s)he have an appropriate education creed? } \\
\text { Is (s)he diligent, faithful to his (her) duties, and a role model? } \\
\text { Does (s)he have cooperative relationships with peer teachers } \\
\text { and embrace students? } \\
\text { Does (s)he perform his (her) own duties actively and voluntarily? }\end{array}$ \\
\hline \multirow{3}{*}{$\begin{array}{l}\text { Work } \\
\text { performance }\end{array}$} & Instruction & $\begin{array}{l}\text { Does (s)he do his (her) best in terms of instructional research } \\
\text { and preparation? } \\
\text { Is (s)he eager to improve teaching methods and coach stu- } \\
\text { dents' learning? } \\
\text { Does (s)he creatively construct education curricula and ef- } \\
\text { ficiently utilise textbooks? } \\
\text { Does (s)he have a proper evaluation plan and use the results } \\
\text { efficiently? }\end{array}$ \\
\hline & $\begin{array}{l}\text { Student } \\
\text { guidance }\end{array}$ & $\begin{array}{l}\text { Is (s)he enthusiastic about education that builds students' } \\
\text { character, and about career guidance? } \\
\text { Does (s)he do his(her) best in school events and student guid- } \\
\text { ance within and/or outside school? } \\
\text { Does (s)he try to understand students' psychological status and } \\
\text { personal problems and provide proper guidance? } \\
\text { Does (s)he show sufficient consideration to students' health and } \\
\text { safety? }\end{array}$ \\
\hline & $\begin{array}{l}\text { Educational } \\
\text { research \& } \\
\text { administrative } \\
\text { service }\end{array}$ & $\begin{array}{l}\text { Does (s)he take the initiative in research and training for his } \\
\text { (her) professional development? } \\
\text { Does (s)he accurately and reasonably deal with his (her) own } \\
\text { duties? } \\
\text { Is (s)he active in performing duties for attaining the educational } \\
\text { goals of the school? } \\
\text { Does (s)he creatively improve and adjust his (her) own duties? }\end{array}$ \\
\hline
\end{tabular}

Table 2. Performance rating for promotion evaluation standards for vice-principals

\begin{tabular}{|c|c|c|}
\hline Areas & Elements & Questions \\
\hline \multirow[t]{2}{*}{$\begin{array}{l}\text { Qualification } \\
\text { \& attitude }\end{array}$} & $\begin{array}{l}\text { Moral character } \\
\text { as an educator }\end{array}$ & $\begin{array}{l}\text { Does (s)he gain the trust and respect of education personnel in } \\
\text { terms of school management? } \\
\text { Does (s)he realise his(her) responsibilities, duties and sense of } \\
\text { mission as an educator? } \\
\text { Does (s)he understand and embrace others' opinions and differ- } \\
\text { ent perspectives? } \\
\text { Does (s)he have integrity and courteousness as an educator? }\end{array}$ \\
\hline & $\begin{array}{l}\text { Attitudes as a } \\
\text { public official }\end{array}$ & $\begin{array}{l}\text { Does (s)he have an appropriate education creed? } \\
\text { Is (s)he diligent, faithful to his (her) duties, and a role model? } \\
\text { Does (s)he make an effort to improve educational planning? } \\
\text { Does (s)he keep his (her) private and public life separate? }\end{array}$ \\
\hline
\end{tabular}




\begin{tabular}{|c|c|c|}
\hline Areas & Elements & Questions \\
\hline \multirow{3}{*}{$\begin{array}{l}\text { Management } \\
\text { \& support }\end{array}$} & $\begin{array}{l}\text { Support for } \\
\text { instructional } \\
\text { activities and } \\
\text { research }\end{array}$ & $\begin{array}{l}\text { Does (s)he identify and solve problems appropriately? } \\
\text { Is his (her) pedagogical consideration of educational activities } \\
\text { appropriate? } \\
\text { Does (s)he assign duties and provide support depending on } \\
\text { teachers' qualifications, capabilities and experience? } \\
\text { Does (s)he efficiently initiate and support teachers' research } \\
\text { and training? }\end{array}$ \\
\hline & $\begin{array}{l}\text { Teacher } \\
\text { support }\end{array}$ & $\begin{array}{l}\text { Does (s)he exercise leadership and make an effort to maintain } \\
\text { order within the school? } \\
\text { Does (s)he evaluate educational activities appropriately? } \\
\text { Does (s)he consider the welfare of school personnel? } \\
\text { Does (s)he listen to and reflect on teachers' opinions regarding } \\
\text { human resource matters in an appropriate manner? }\end{array}$ \\
\hline & $\begin{array}{l}\text { Administration } \\
\& \text { management }\end{array}$ & $\begin{array}{l}\text { Does (s)he deal with office matters reasonably, accurately and } \\
\text { appropriately? } \\
\text { Does (s)he appropriately modify and apply internal regulations } \\
\text { and rules? } \\
\text { Does (s)he effectively utilise educational facilities and equip- } \\
\text { ment? } \\
\text { Does (s)he take appropriate actions on school safety? }\end{array}$ \\
\hline
\end{tabular}

\section{The Performance-Based Pay System}

In 2001, a performance-based pay system for public education officials was introduced, along with a performance-based pay system for general public officials. Following the financial crisis of the late 1990s, the Korean government aimed to foster a creative and performance-based work environment for public officials by complementing the seniority-based personnel management system with a performance-based one (Lee, Yoon, Kwak, \& Lee, 2014). In particular, the system for public education officials was adopted in order to encourage constructive competition between teachers, to make monetary rewards for teachers' efforts available, and ultimately to regain public trust in the education system (Ministry of Education, 2001).

Teachers, vice-principals and principals are all evaluated in terms of the performance-based pay system. When the system was first adopted, 90\% of an individual's remuneration was based on performance, with the remaining $10 \%$ being evenly distributed. Due to extreme backlash from teachers, the ratio was changed in the period from 2002 to 2005 , so that $10 \%$ was performance-based and $90 \%$ was evenly distributed; however, the pay ratio based on performance subsequently gradually increased to 50\% (Park, 2010).

In 2011, school performance was incorporated into the performancebased pay system (Ministry of Education, Science and Technology, 2010), with $90 \%$ of remuneration being based on individual performance and $10 \%$ on school performance in the first year. These ratios changed to $80 \%$ and $20 \%$, respectively, in 2012 . Of the $80 \%$ of remuneration related to individual performance, the 
teacher's individual performance accounts for approximately 50\%, with the remaining 50\% being distributed evenly among teachers within a school based on the school's performance. Currently, the abolition of the school performancebased pay system is under discussion, due to a range of drawbacks and problems arising over the past five years (Ministry of Education, 2015).

Theoretically, each school is required to develop its own standards for performance-based pay; however, the Ministry of Education distributes guidelines and illustrative examples of the standards to the schools in each district. Table 3 presents an example of the 2015 evaluation standards for school performance-based pay from the Gyeonggi Provincial Office of Education. The evaluation areas are "instruction", "student guidance", "administrative service" and "professional development". Since the evaluation standards for the performance-based pay system are determined by each school, the standards used vary from one school to another.

This type of evaluation is norm-based, whereby the top 30\% of teachers within a school receive a ranking of S, the next $40 \%$ an $\mathrm{A}$, and the remaining $30 \%$ a B. Remuneration incentives are then distributed to each group based on the evaluation results.

Table 3. An example of evaluation standards in the performance-based pay system

\begin{tabular}{|c|c|c|c|}
\hline Area & Elementary school & Middle school & High school \\
\hline \multirow{6}{*}{ Instruction } & $\begin{array}{l}\text { Number of teaching } \\
\text { hours }\end{array}$ & $\begin{array}{l}\text { Number of teaching } \\
\text { hours }\end{array}$ & Number of teaching hours \\
\hline & $\begin{array}{l}\text { Frequency of class } \\
\text { demonstrations, etc. }\end{array}$ & $\begin{array}{l}\text { Frequency of class dem- } \\
\text { onstrations }\end{array}$ & $\begin{array}{l}\text { Frequency of class dem- } \\
\text { onstrations }\end{array}$ \\
\hline & & $\begin{array}{l}\text { Guidance for student } \\
\text { development }\end{array}$ & $\begin{array}{l}\text { Guidance for student } \\
\text { development }\end{array}$ \\
\hline & & $\begin{array}{l}\text { Guidance for self-govern- } \\
\text { ing activities }\end{array}$ & $\begin{array}{l}\text { Guidance for self-govern- } \\
\text { ing activities }\end{array}$ \\
\hline & & $\begin{array}{l}\text { Teaching students in } \\
\text { multi-grades and multi- } \\
\text { subjects, etc. }\end{array}$ & $\begin{array}{l}\text { Teaching students in } \\
\text { multi-grades and multi- } \\
\text { subjects }\end{array}$ \\
\hline & & & $\begin{array}{l}\text { Guiding evening self- } \\
\text { study sessions, etc. }\end{array}$ \\
\hline \multirow{3}{*}{$\begin{array}{l}\text { Student } \\
\text { guidance }\end{array}$} & $\begin{array}{l}\text { Performance of parent } \\
\text { consultation }\end{array}$ & $\begin{array}{l}\text { Performance of parent } \\
\text { consultation }\end{array}$ & $\begin{array}{l}\text { Performance of parent } \\
\text { consultation }\end{array}$ \\
\hline & $\begin{array}{l}\text { Performance of student } \\
\text { consultation }\end{array}$ & $\begin{array}{l}\text { Performance of student } \\
\text { consultation }\end{array}$ & $\begin{array}{l}\text { Performance of student } \\
\text { consultation }\end{array}$ \\
\hline & $\begin{array}{l}\text { Guiding student com- } \\
\text { muting and school } \\
\text { meals, etc. }\end{array}$ & $\begin{array}{l}\text { Guiding student commut- } \\
\text { ing and school meals, etc. }\end{array}$ & $\begin{array}{l}\text { Guiding student commut- } \\
\text { ing and school meals, etc. }\end{array}$ \\
\hline
\end{tabular}




\begin{tabular}{|c|c|c|c|}
\hline Area & Elementary school & Middle school & High school \\
\hline \multirow{11}{*}{$\begin{array}{l}\text { Administrative } \\
\text { contribution }\end{array}$} & Home room teacher & Home room teacher & Home room teacher \\
\hline & $\begin{array}{l}\text { Difficulty levels of ad- } \\
\text { ministrative service }\end{array}$ & $\begin{array}{l}\text { Difficulty levels of admin- } \\
\text { istrative service }\end{array}$ & $\begin{array}{l}\text { Difficulty levels of admin- } \\
\text { istrative service }\end{array}$ \\
\hline & $\begin{array}{l}\text { Performing tasks avoid- } \\
\text { ed by other teachers }\end{array}$ & $\begin{array}{l}\text { Performing tasks avoided } \\
\text { by other teachers }\end{array}$ & $\begin{array}{l}\text { Performing tasks avoided } \\
\text { by other teachers }\end{array}$ \\
\hline & $\begin{array}{l}\text { Guiding students' prize- } \\
\text { winning experiences }\end{array}$ & $\begin{array}{l}\text { Guiding students' prize- } \\
\text { winning experiences }\end{array}$ & $\begin{array}{l}\text { Guiding students' prize- } \\
\text { winning experiences }\end{array}$ \\
\hline & $\begin{array}{l}\text { Keeping absenteeism } \\
\text { and tardiness records }\end{array}$ & $\begin{array}{l}\text { Keeping absenteeism and } \\
\text { tardiness records }\end{array}$ & $\begin{array}{l}\text { Keeping absenteeism and } \\
\text { tardiness records }\end{array}$ \\
\hline & $\begin{array}{l}\text { Being in charge of op- } \\
\text { erating model or policy } \\
\text { research school }\end{array}$ & $\begin{array}{l}\text { Being in charge of } \\
\text { operating model or policy } \\
\text { research school }\end{array}$ & $\begin{array}{l}\text { Being in charge of } \\
\text { operating model or policy } \\
\text { research school }\end{array}$ \\
\hline & $\begin{array}{l}\text { Being in charge of a } \\
\text { special or integrated } \\
\text { classroom }\end{array}$ & $\begin{array}{l}\text { Being in charge of a } \\
\text { special or integrated } \\
\text { classroom }\end{array}$ & $\begin{array}{l}\text { Being in charge of a } \\
\text { special or integrated } \\
\text { classroom }\end{array}$ \\
\hline & $\begin{array}{l}\text { Difficulty level of grade } \\
\text { of which the teacher is } \\
\text { in charge }\end{array}$ & Guiding club activities & Guiding club activities \\
\hline & & $\begin{array}{l}\text { Teaching students for } \\
\text { academic contests }\end{array}$ & $\begin{array}{l}\text { Teaching students for } \\
\text { academic contests }\end{array}$ \\
\hline & & $\begin{array}{l}\text { Manager of a subject } \\
\text { area, etc. }\end{array}$ & Manager of a subject area \\
\hline & & & $\begin{array}{l}\text { Guidance for students } \\
\text { entering a higher grade } \\
\text { school or employment, etc }\end{array}$ \\
\hline \multirow{7}{*}{$\begin{array}{l}\text { Professional } \\
\text { development }\end{array}$} & $\begin{array}{l}\text { Number of training } \\
\text { hours }\end{array}$ & Number of training hours & Number of training hours \\
\hline & $\begin{array}{l}\text { Obtaining professional } \\
\text { certificates related to } \\
\text { educational activities }\end{array}$ & $\begin{array}{l}\text { Obtaining professional } \\
\text { certificates related to } \\
\text { educational activities }\end{array}$ & $\begin{array}{l}\text { Obtaining professional } \\
\text { certificates related to } \\
\text { educational activities }\end{array}$ \\
\hline & $\begin{array}{l}\text { Winning an award for } \\
\text { educational research }\end{array}$ & $\begin{array}{l}\text { Winning an award for } \\
\text { educational research }\end{array}$ & $\begin{array}{l}\text { Winning an award for } \\
\text { educational research }\end{array}$ \\
\hline & $\begin{array}{l}\text { Playing a role as teach- } \\
\text { ing supervisor }\end{array}$ & $\begin{array}{l}\text { Playing a role as teaching } \\
\text { supervisor }\end{array}$ & $\begin{array}{l}\text { Playing a role as teaching } \\
\text { supervisor }\end{array}$ \\
\hline & $\begin{array}{l}\text { Performance of educa- } \\
\text { tional development and } \\
\text { research }\end{array}$ & $\begin{array}{l}\text { Performance of educa- } \\
\text { tional development and } \\
\text { research }\end{array}$ & $\begin{array}{l}\text { Performance of educa- } \\
\text { tional development and } \\
\text { research }\end{array}$ \\
\hline & $\begin{array}{l}\text { Winning other awards, } \\
\text { etc. }\end{array}$ & Winning other awards & Winning other awards \\
\hline & & $\begin{array}{l}\text { Participating in subject } \\
\text { study communities, etc. }\end{array}$ & $\begin{array}{l}\text { Participating in subject } \\
\text { study communities, etc. }\end{array}$ \\
\hline
\end{tabular}

\section{Teacher Evaluation for Professional Development}

In 2004, the OECD reported that the existing Korean teacher evaluation system (i.e., teacher performance rating for promotion) had certain critical 
problems (Coolahan, Santiago, Phair, \& Ninomiya, 2004). One of the most urgent problems was the fact that the performance rating for promotion system does not relate to teachers' professional development. Thus, this system failed to formally encourage or require poorer performing teachers to take action to enhance their performance. In other words, the evaluation process failed to supply Korean teachers with constructive feedback, advice or learning opportunities. One of the main reasons for this was the lack of clear, concrete and systematic evaluation standards and procedures. In time, Korean researchers began to voice concerns regarding the problems associated with the teacher performance rating for promotion system (Lee, 2006). Subsequently, in 2004, the Minister of Education announced the development of a new system based on a pool of stakeholders' opinions for the purposes of both the professional development of teachers and the reduction of private tutoring expenditure (Ministry of Education \& Human Resource Development, 2005). Consequently, the teacher evaluation system for professional development was developed and implemented in accordance with departmental directions in 2005. The purpose of this particular evaluation system was to develop the skills and abilities of teachers, including principals and vice-principals, by providing productive feedback and customised training programmes (Ministry of Education \& $\mathrm{Hu}$ man Resource Development, 2006).

This system is used to evaluate regular teachers, including master teachers, principals and vice-principals, in elementary, middle, high and special schools. In accordance with related legislation, all teachers must participate in such evaluations for professional development. In additional, in order to elicit 360-degree feedback, students and their parents, as well as principals, vice-principals and peer teachers, participate in the process as evaluators. Furthermore, three groups of stakeholders evaluate all teachers in order to ensure the concreteness of results. The first group is comprised of more than five peer teachers, including at least either the principal or vice-principal and at least either the master teacher or head teacher of the respective school. This group focuses on evaluating the teacher's teaching performance (i.e., peer-teacher evaluation). The second group comprises all of the students taught by the teacher in the respective year. Students are required to rate their level of satisfaction with their classes (i.e., student-class satisfaction). The third group includes the parents of these students. Specifically, parents rate their levels of satisfaction with their child's teachers and school. In the case of master teachers, the groups are similar, except that the principal, vice-principal and head teacher do not necessarily need to act as evaluators. Finally, the principal and vice-principal of every school are evaluated by parents and teachers, but not by students. 
Tables 4 and 5 offer overviews of the standards for the professional development evaluation of regular teachers (i.e., standards for peer-teacher evaluation), principals and vice-principals.

Table 4. Teacher evaluation for professional development evaluation standards for regular teachers

\begin{tabular}{|c|c|c|c|}
\hline Areas & Elements & \multicolumn{2}{|l|}{ Criteria } \\
\hline \multirow{3}{*}{ Instruction } & Preparation & \multicolumn{2}{|c|}{$\begin{array}{l}\text { Understanding the curriculum and making an effort to } \\
\text { improve teaching \& learning methods } \\
\text { Conducting learner analysis \& instructional analysis } \\
\text { Establishing teaching \& learning strategies }\end{array}$} \\
\hline & Implementation & $\begin{array}{l}\text { Introduction } \\
\text { Teacher attitude } \\
\text { Instructional materials } \\
\text { Summary \& synthesis }\end{array}$ & $\begin{array}{l}\text { Teacher questioning } \\
\text { Interaction between teacher } \\
\text { and students } \\
\text { Teaching activities }\end{array}$ \\
\hline & $\begin{array}{l}\text { Assessment \& } \\
\text { utilisation }\end{array}$ & \multicolumn{2}{|c|}{$\begin{array}{l}\text { Assessment of student learning (Criteria \& methods) } \\
\text { Utilisation of assessment results }\end{array}$} \\
\hline \multirow{2}{*}{$\begin{array}{l}\text { Student } \\
\text { guidance }\end{array}$} & Personal maturity & \multicolumn{2}{|c|}{$\begin{array}{l}\text { Understanding students' personal problems \& develop } \\
\text { strong character and creativity } \\
\text { Student guidance in collaboration with their parents } \\
\text { Career guidance considering students' aptitudes and } \\
\text { strengths }\end{array}$} \\
\hline & Social Maturity & \multicolumn{2}{|c|}{$\begin{array}{l}\text { Cultivating good habits } \\
\text { Enhancing adaptability at school } \\
\text { Developing democratic citizenship }\end{array}$} \\
\hline
\end{tabular}

Table 5. Teacher evaluation for professional development evaluation standards for principals and vice-principals

\begin{tabular}{|c|c|c|c|}
\hline \multirow{2}{*}{ Area } & \multirow{2}{*}{ Elements } & \multicolumn{2}{|c|}{ Criteria } \\
\hline & & Principals & Vice-principals \\
\hline \multirow{4}{*}{$\begin{array}{l}\text { School } \\
\text { management }\end{array}$} & $\begin{array}{l}\text { Educational } \\
\text { planning }\end{array}$ & $\begin{array}{l}\text { Management of educa- } \\
\text { tional goals at the individual } \\
\text { school level } \\
\text { Curriculum organisation \& } \\
\text { management } \\
\text { Management of academic } \\
\text { affairs and students }\end{array}$ & $\begin{array}{l}\text { Support for management } \\
\text { of educational goals at the } \\
\text { individual school level } \\
\text { Support for curriculum organ- } \\
\text { isation \& management } \\
\text { Management of academic } \\
\text { affairs and students }\end{array}$ \\
\hline & $\begin{array}{l}\text { School } \\
\text { supervision }\end{array}$ & $\begin{array}{l}\text { Improvement of teachers' } \\
\text { teaching skills } \\
\text { Autonomous supervision }\end{array}$ & $\begin{array}{l}\text { Support for improvement of } \\
\text { teachers' teaching skills } \\
\text { Support for autonomous } \\
\text { supervision }\end{array}$ \\
\hline & Personnel affairs & $\begin{array}{l}\text { School personnel manage- } \\
\text { ment }\end{array}$ & $\begin{array}{l}\text { Conducting school personnel } \\
\text { affairs }\end{array}$ \\
\hline & Facility \& budget & $\begin{array}{l}\text { Facilities management } \\
\text { Budget compilation \& } \\
\text { execution }\end{array}$ & \\
\hline
\end{tabular}


The checklist for peer-teacher evaluation and the two questionnaires for measuring student and parental levels of satisfaction contain five-point Likert scale items for each criterion, as well as a number of open-ended questions. Classroom observations and reviews of relevant information and/or documentation inform the teacher evaluation for professional development.

The evaluation results are available to the various stakeholders, including teachers, parents and municipalities. All teachers are subsequently required to develop an individual professional development plan based on the evaluation results. In accordance with such plans, individual teachers are required to participate in training programmes offered by schools, each Municipal Ministry of Education, and others.

\section{Comparative Analysis of the Three Teacher Evaluation Systems}

The three Korean teacher evaluation systems for primary and secondary education described above both converge and diverge in certain respects in terms of purpose, stakeholders, evaluators, scope of evaluation, criteria and standards, and methods and instruments (see Table 6). In particular, the purposes of the three systems differ from one another. The evaluation for professional development system aims to improve teachers' expertise through a formative evaluation of their strengths and weaknesses in both instruction and student guidance. On the other hand, the common purpose of the performance rating for promotion and the performance-based pay systems is to provide teachers with rewards based on their job performance, determined through summative evaluations.

The relevant stakeholders of all three systems include representatives from the national and regional governments, teachers, teacher unions, principals, parents and students. All three systems also share similar targets of evaluation (i.e., principals, vice-principals and teachers), except that principals are excluded from the performance rating for promotion system, and the performance-based pay system considers the performance of individual schools as well as that of teachers. It is compulsory for all national and public primary and secondary schools to implement the three systems, while private primary and secondary schools are strongly encouraged to adopt the system of teacher evaluation for professional development. The main evaluators for all three systems are principals, vice-principals and teachers; however, the teacher evaluation for professional development system also includes students and their parents as evaluators. 
In terms of evaluation criteria and standards, the common evaluation areas shared by the three teacher evaluation systems are instruction and student guidance for teacher evaluation, as well as school management and support for the evaluation of principals and vice-principals. In addition to these common evaluation areas, the performance rating for promotion system includes "qualification and attitude", and the performance-based pay system involves two additional evaluation areas: "administrative contribution" and "efforts toward professional development". As indicated in Tables 1 to 5 , the evaluation criteria and standards of the three systems differ somewhat in terms of evaluation areas and purposes. Unfortunately, none of the three systems provides clear rubrics for fair, accurate and reliable assessment in terms of evaluation standards.

With regard to instruments, all three systems use a checklist as the main evaluation instrument for each criterion. In terms of the type of data collected, the performance-based pay system mainly collects quantifiable data (e.g., number of teaching hours, frequency of class demonstrations, absenteeism and tardiness records, etc.). However, the performance rating for promotion system uses a checklist targeting the subjective opinions of the evaluators (e.g., Does (s)he have integrity and courteousness as an educator?). The teacher evaluation for professional development system collects evaluators' subjective opinions on the individual teacher's instruction and student guidance through a number of open-ended questions, in addition to the checklist items that collect quantitative information.

Based on Darling-Hammond's (2013) six criteria for an effective teacher evaluation system, the three Korean systems contain serious deficiencies. The systems meet the criterion of having "panels of teachers and administrators oversee the evaluation process", in that evaluation committees oversee each evaluation process. In addition, the teacher evaluation for professional development system meets the criterion that "evaluation should be accompanied by useful feedback, and connected to professional development opportunities". However, the three Korean systems do not meet any of the other established criteria. 
Table 6. Comparison of the three teacher evaluation systems

\begin{tabular}{|c|c|c|c|}
\hline $\begin{array}{l}\text { Analytical } \\
\text { Lenses }\end{array}$ & $\begin{array}{l}\text { Teacher Evaluation for } \\
\text { Professional Develop- } \\
\text { ment }\end{array}$ & $\begin{array}{l}\text { Performance Rating for } \\
\text { Promotion }\end{array}$ & $\begin{array}{l}\text { Performance-Based Pay } \\
\text { System }\end{array}$ \\
\hline \multirow[t]{2}{*}{ Purposes } & $\begin{array}{l}\text { Teachers' professional } \\
\text { development }\end{array}$ & $\begin{array}{l}\text { Assisting promotions } \\
\text { and school transfers }\end{array}$ & $\begin{array}{l}\text { Distributing monetary } \\
\text { incentives based on } \\
\text { individual and school } \\
\text { performance }\end{array}$ \\
\hline & Formative & Summative & Summative \\
\hline Stakeholders & $\begin{array}{l}\text { National and regional } \\
\text { governments, teachers, } \\
\text { teacher unions, principals, } \\
\text { parents and students }\end{array}$ & $\begin{array}{l}\text { National and regional } \\
\text { governments, teach- } \\
\text { ers, teacher unions, } \\
\text { principals, parents and } \\
\text { students }\end{array}$ & $\begin{array}{l}\text { National and regional } \\
\text { governments, teach- } \\
\text { ers, teacher unions, } \\
\text { principals, parents and } \\
\text { students }\end{array}$ \\
\hline Evaluators & $\begin{array}{l}\text { Principals, vice-principals, } \\
\text { teachers, students, } \\
\text { parents }\end{array}$ & $\begin{array}{l}\text { Principals ( } 40 \%), \\
\text { vice-principals (30\%), } \\
\text { teachers (30\%) }\end{array}$ & N/A \\
\hline \multirow[b]{2}{*}{$\begin{array}{l}\text { Scope of } \\
\text { evaluation }\end{array}$} & $\begin{array}{l}\text { Principals, vice-principals, } \\
\text { teachers }\end{array}$ & $\begin{array}{l}\text { Vice-principals, teach- } \\
\text { ers }\end{array}$ & $\begin{array}{l}\text { Principals, vice-princi- } \\
\text { pals, teachers, schools }\end{array}$ \\
\hline & $\begin{array}{l}\text { Annually implemented, } \\
\text { compulsory } \\
\text { Public and national } \\
\text { schools (strongly recom- } \\
\text { mended for private } \\
\text { schools) }\end{array}$ & $\begin{array}{l}\text { Annually implemented, } \\
\text { compulsory } \\
\text { Public and national } \\
\text { schools }\end{array}$ & $\begin{array}{l}\text { Annually implemented, } \\
\text { compulsory } \\
\text { Public and national } \\
\text { schools }\end{array}$ \\
\hline \multirow{3}{*}{$\begin{array}{l}\text { Criteria \& } \\
\text { standards }\end{array}$} & $\begin{array}{l}\text { Principals/Vice-principals: } \\
\text { School management }\end{array}$ & $\begin{array}{l}\text { Vice-principals: Quali- } \\
\text { fication and attitudes, } \\
\text { management and } \\
\text { support }\end{array}$ & $\begin{array}{l}\text { Principals/Vice-princi- } \\
\text { pals: Varying in metro- } \\
\text { politan and provincial } \\
\text { offices of education }\end{array}$ \\
\hline & $\begin{array}{l}\text { Teachers: Instruction \& } \\
\text { student guidance }\end{array}$ & $\begin{array}{l}\text { Teachers: Qualification } \\
\text { and attitudes, work } \\
\text { performance }\end{array}$ & $\begin{array}{l}\text { Teachers: Instruction, } \\
\text { student guidance, } \\
\text { administrative contri- } \\
\text { bution, professional } \\
\text { development }\end{array}$ \\
\hline & & & $\begin{array}{l}\text { School performance: } \\
\text { Improvement in } \\
\text { scholastic achievement, } \\
\text { operation of specialised } \\
\text { events, participation } \\
\text { rate in after-school } \\
\text { programmes, etc. }\end{array}$ \\
\hline \multirow[t]{2}{*}{$\begin{array}{l}\text { Methods \& } \\
\text { instruments }\end{array}$} & $\begin{array}{l}\text { Checklist including five- } \\
\text { point Likert scaled ques- } \\
\text { tions and open-ended } \\
\text { questions } \\
\text { Survey questionnaire for } \\
\text { students and parents } \\
\text { including open-ended } \\
\text { questions }\end{array}$ & $\begin{array}{l}\text { Checklist collecting } \\
\text { both quantitative and } \\
\text { qualitative information }\end{array}$ & $\begin{array}{l}\text { Checklist collecting } \\
\text { mainly quantitative } \\
\text { information }\end{array}$ \\
\hline & Criterion-referenced & Ranking & $\begin{array}{l}\text { Norm-referenced } \\
\text { (S-30\%, A-40\%, B-30\%) }\end{array}$ \\
\hline
\end{tabular}




\section{Discussion and Conclusion}

The three teacher evaluation systems described above have been applied in Korea since teacher evaluation for professional development was launched nationwide in 2010. However, the evaluation results obtained from the three different systems for an individual teacher have often been inconsistent, consequently raising issues of reliability and fairness (Jeon, Cho, Shin, \& Kim, 2008; Kim, 2008). In addition, the increased workload for teachers and school administrators has been criticised (Jeon et al., 2008). This has led stakeholders to posit that an improved teacher evaluation system is required.

An ideal teacher evaluation system would be a single comprehensive system with multiple functions as a vehicle of evaluation for promotion, monetary reward, collegial learning and professional development (DarlingHammond, 2013). Such a single comprehensive system should include a variety of evaluation criteria and standards meeting multiple purposes. This feature would enable evaluators to assess teachers at any time, as users could select the criteria and standards suitable to their purposes. A single teacher evaluation system may be far more efficient and economical in helping teachers to enhance their expertise and in allowing schools and municipal education offices both to recognise outstanding teachers and to offer the services and developmental opportunities required for those who teach less effectively.

For the above reasons, it is imperative to integrate the three separate Korean systems into one system with multiple purposes for both summative and formative evaluations. The analysis results in Table 6 show the commonalities between the systems in terms of stakeholders, evaluators, scope, criteria and methods, further supporting the rationale for developing a single comprehensive teacher evaluation system in Korea. Such a comprehensive evaluation system may allow schools and municipal education offices to simplify redundant administrative procedures, alleviate teachers' workloads and psychological burdens, and contribute to fewer time and financial constraints related to teacher evaluation.

An initial step in developing a single comprehensive teacher evaluation system is to establish standards for teaching that are consistent with standards for student learning, as all teaching activities ultimately aim to enhance student learning. An evaluation system with standards for teaching aligned with those for student learning might allow teachers to focus on supporting their students' learning, rather than concentrating only on their own teaching practices. One appropriate strategy to develop such an evaluation system might be to adopt value-added methods in determining the effectiveness of teaching practices. 
Value-added analyses of student test score gains ascribed to individual teachers does have certain shortcomings, such as the difficulty of distinguishing student progress resulting from teaching efforts from those resulting from other possible factors influencing student learning, such as out-of-school private tutoring, home conditions and peer relationships (McCaffrey, Koretz, Lockwood, \& Hamilton, 2005). In order to alleviate these issues, a variety of evidence regarding student accomplishments associated with teaching activities selected by teachers themselves should be used (Darling-Hammond, 2013). Such evidence might include both alternative and traditional assessments, such as portfolios, essays and science investigation reports, as well as pre- and posttest measures of student learning.

It is undeniable that the ultimate goal of teaching is to enhance student learning. This implies that a teacher evaluation system should examine precisely the practical aspects of teaching directly related to student learning. Accordingly, the critical evaluation elements of a teacher evaluation system should include the results of student learning as well as various sources of evidence supporting teachers' actual accomplishments. One way to put this into practice might be to have teachers set customised learning goals for each individual student at the beginning of the semester and to monitor students' progress by assessing their academic performance through multiple appropriate measuring tools.

Moreover, a number of scholars (Goddard, Goddard, \& TschannenMoran, 2007; Jackson \& Bruegmann, 2009) have suggested that collaborative learning among teachers has a positive influence on supporting student learning and on student academic achievement. Such findings imply that a revised Korean teacher evaluation system should include standards for teacher collaboration in order to improve student academic performance. Such a teacher evaluation system would encourage teachers to collaborate actively with one another to support student learning, in turn fostering collegial learning and enhancing their own expertise. Collaborative work among teachers for learning and exchanging new teaching strategies and skills may be a particularly effective and practical manner of professional development.

One of the most serious drawbacks common to the current Korean teacher evaluation systems is the absence of clear standards for desirable teaching practices with concrete rubrics based on related research findings. It appears that the developers of the current systems assumed that listing general components of good teaching practices would suffice. Unfortunately, little attention was paid to the development of rubrics to help evaluators to clearly, accurately, consistently and fairly assess the effectiveness of the individual teacher's teaching practices. As a result, it is difficult for evaluated teachers to 
identify what steps they should take to improve or enhance their own teaching and student learning. In conclusion, the development of a detailed and concrete rubric for every standard is essential for an effective teacher evaluation system in the context of Korean primary and secondary education.

\section{Acknowledgment:}

This work was supported by the Hongik University Research Fund.

\section{References}

Choi, H. J., \& Park, J. H. (2013). Historical analysis of the policy on the college entrance system in South Korea. International Education Studies, 6(11), 106-121.

Clayton, C. (2013). Understanding current reforms to evaluate teachers: A literature review on teacher evaluation across the career span. Retrieved 16. 5. 2015 from http://scholar.google.co.kr/schol ar? $\mathrm{q}=$ Understanding+current + reforms+to+evaluate+teachers $\% 3 \mathrm{~A}+\mathrm{A}+$ literature +review+on+teacher +evaluation+across+the+career+span $\& b \operatorname{tnG}=\& h l=k o \& a s \_s d t=0 \% 2 C_{5}$.

Coolahan, J., Santiago, P., Phair, R., \& Ninomiya, A. (2004). Attracting, developing, and retaining effective teachers-country note: Korea. Paris: OECD Education and Training Policy Division. Darling-Hammond, L. (2013). Getting teacher evaluation right: What really matters for effectiveness and improvement. New York: Teachers College Press.

Goddard, Y. L., Goddard, R. D., \& Tschannen-Moran, M. (2007). Theoretical and empirical investigation of teacher collaboration for school improvement and student achievement in public elementary schools. Teachers College Record, 109(4), 877-896.

GreatKids (n.d.). What makes a great teacher? Retrieved 16. 7. 2015 from http://www.greatschools. org/gk/articles/what-makes-a-great-teacher/.

Isoré, M. (2009). Teacher evaluation: Current practices in OECD countries and a literature review. OECD Education Working Papers, No. 23, OECD Publishing. http://dx.doi.org/10.1787/223283631428. Jackson, C. K., \& Bruegmann, E. (2009). Teaching students and teaching each other: The importance of peer learning for teachers. Washington, DC: National Bureau of Economic Research.

Jeon, J. S. (2009). Alternative exploring of improvement and unification for the multi policy of teachers' evaluation system. The Journal of Korean Teacher Education, 26(2), 387-410.

Jeon, J. S., Cho, D. S., Shin, S. M., \& Kim, S. Y. (2008). Utilization of the results from the teacher evaluation for professional development. The Ministry of Education, Science, and Technology Research Report.

Kang, Y. W., \& Kim, J. H. (2004). Directions of the performance rating for the professional development of teachers. Korean Policy Sciences Review, 8(1), 149-174.

Kim, H., \& Joo, Y. (2014). A discriminant analysis of the effect of teacher evaluation system for professional development and performance appraisal system on rating of performance-based pay system. The Journal of Korean Teacher Education, 31(3), 59-80. 
Kim, K. T., Park, K. Y., \& Joo, Y. H. (2009). A political analysis of teacher evaluation policy streams in Korea. The Journal of Politics of Education, 16(1), 35-61.

Kim, K., Jung, M., Jeon, J., Shin, S., \& Kang, S. (2010). A study on how to re-establish teacher evaluation system. Korean Educational Development Institute Research Report RR 2010-10. Lee, J. H. (2006). The study of limit factors embedded in the decision-making process of merit pay: Based on the path dependency of new institutionalism. Journal of Educational Studies, 37(1), 77-10o. Lee, J. S., Yoon, Y. J., Kwak, C. K., \& Lee, J. W. (2014). New public administration 2.o. Seoul: Daeyoung Co.

Lee, Y. S. (2006). Development trends of teacher evaluation system in foreign countries. The Journal of Korean Teacher Education, 23(1), 98-145.

McCaffrey, D. F., Koretz, D., Lockwood, J. R., \& Hamilton, L. S. (2005). Evaluating value-added models for teacher accountability. Santa Monica, CA: RAND Corporation.

Ministry of Education (2015). Public hearing on the improvement of teacher evaluation system (press release)

Ministry of Education and Human Resource Development (2005). Public hearing on the improvement of teacher evaluation system (press release).

Ministry of Education and Human Resource Development (2006). Policy initiative on the teacher evaluation for professional development (press release).

Ministry of Education, Science, and Technology (2001). The implementation plan of performancebased pay system for educational public officials (press release).

Ministry of Education, Science, and Technology (2010). Guidelines on the performance-based payment for educational public officials (press release).

National Commission on Teaching and America's Future (2005). Induction into learning communities.

Washington, D. C.: National Commission on Teaching and America's Future.

Park, C. H. (2010). A study of performance-based pay system development in the history of public administrative perspective: Focused on the system of performance-based pay for teachers. Korea Public Administration History Review, $27(12)$, 55-79.

Park, J., Choi, J., \& Choi, C. (2009). Exploration of the applicability of the new teacher evaluation or the teacher performance rating. Educational Research, 29(1), 103-122.

Strong, J. H., \& Tucker, P. D. (2012). Handbook on teacher evaluation: Assessing and improving performance. Moorabbin, VIC: Hawker Brownlow Education.

Toch, T., \& Rothman, R. (2008). Rush to judgment: Teacher evaluation in public education. ERIC Document No: ED502120. 


\section{Biographical note}

HeE Jun Chor is an associate professor in the Department of Education at Hongik University, Seoul, Korea. He received his Ph.D. from the University of Illinois at Urbana-Champaign. His research interests focus on problembased video instruction, the design of e-learning enriched interactive learning environments, teacher and program evaluation, transfer of learning and educational uses of various technologies.

Ji-Hye PARK is an associate professor in the Department of Education at Kookmin University, Seoul, Korea. She received her Ph.D. from the University of Illinois at Urbana-Champaign. Her research interests include program evaluation, transfer of training, teacher evaluation and development, utilization technology for effective teaching and learning and career development. 